\title{
Study of the histopathological types of cutaneous melanoma in Palmas-TO from 2001 to $2011^{*}$
}

\author{
Nilo Fernandes da Costa ${ }^{1}$ \\ Myrlena Regina Machado Mescouto Borges ${ }^{1}$
}

\author{
Nurimar Conceição Fernandes²
}

DOI: http:/ /dx.doi.org/10.1590/abd1806-4841.20153528

\begin{abstract}
BACKGROUND: Cutaneous melanoma (CM) is considered serious for causing frequent metastasis, presenting high mortality, resistance to available therapies and incidences in laboring activity.

OвJECTIVES: To study the histopathological types of cutaneous melanoma in Palmas-TO from 2001 to 2011, according to risk factors, location of lesions, Clark levels and Breslow thickness.

Methods: A descriptive, retrospective and quantitative research in reports of the Serviços de Anatomia Patológica in Palmas (SAPP) and Registro de Câncer de Base Populacional de Palmas (RCBPP).

REsults: The years of highest incidences were: 2004 (8 cases/17.8\%), 2008 and 2011 (7 cases each/15.6\%) and 2010 (6 cases/13.3\%). Among the 45 cases studied, there were predominance in patients between 41 and 60 years old, women, caucasians, farmers, located in trunk, in situ type, superficial extensive and metastatic cutaneous, Clark levels I (20\%) and IV (17.7\%), Breslow thickness $\leq 1 \mathrm{~mm}(35.5 \%)$ and 2.01 to $4 \mathrm{~mm}(24.4 \%)$.

CONCLUSIONS: The most common histopathological types were: cutaneous melanoma in situ, superficial extensive and metastatic, followed by nodular cutaneous melanoma, and finally, by other forms. In this study, Clark levels and Breslow thickness pointed to greater importance of thin melanomas and sun exposure without appropriate protection in farmers.
\end{abstract}

Keywords: Epidemiology; Melanoma; Occupational diseases; Pathology; Skin neoplasms; Workers

\section{INTRODUCTION}

Cutaneous melanoma $(\mathrm{CM})$ originates from melanocytes, representing about $4 \%$ of all malignant skin tumors and featuring an increasing frequency in Brazil and in several countries around the world. It is clinically characterized, for the most part, by the presence of hyperchromic macula with color variation and irregular borders. It is the most serious of skin cancers due to its frequent metastases, high mortality - especially in lesions with late diagnosis - and resistance to available therapies (chemotherapy and radiotherapy). ${ }^{1,2}$

Incidence of CM in Brazil is higher in the South and Southeast regions and, according to estimates by Instituto Nacional do Câncer (INCA) in 2006, the disease affected 4 to 6 people per 100,000 inhabitants. In Central West region, according to the same estimate, CM affected 1.96 women and 1.77 men per 100,000 inhabitants. . $^{1,2,3,4}$
As an occupational disease, CM involves several risk factors that should be considered: arsenic and its arsenic compounds; tarmac, pitch, bitumen, mineral coal, paraffin, creosote, tar, oil shale and waste products from these substances; ionizing radiation; UV; and mineral lubricating oils. ${ }^{5}$

Considering the illness of workers exposed to the sun and its relationship to labor, such exposure may contribute to the development of skin cancers, especially in groups as postmen, farmers, fishermen and all individuals who perform labor activity outdoors. ${ }^{6}$

$\mathrm{CM}$ is not a malignant neoplasm of compulsory notification, so its records and mappings are obtained by active searches or researches as this study.

In the city of Palmas, located in the State of Tocantins in the Northern region of Brazil, the extremely dry weather, hot and adverse for most of the year, favors a permanent exposure to ultraviolet radiation

\footnotetext{
Received on 11.03.2014.

Approved by the Advisory Board and accepted for publication on 12.11.2014.

Study performed at Universidade Federal do Tocantins (UFT) - Palmas (TO), Brazil.

Financial Support: None.

Conflict of Interest: None.

Universidade Federal do Tocantins (UFT) - Palmas (TO), Brazil.

Universidade Federal do Rio de Janeiro (UFRJ) - Rio de Janeiro (RJ), Brazil

C2015 by Anais Brasileiros de Dermatologia
} 
(UVR) of its inhabitants. We must take into consideration that the finding of early CM lesion consists of the first and often the only effective opportunity of diagnosis and curative treatment of this neoplasia. ${ }^{7}$

Considering that Palmas presents an epidemiological scenario suitable to the disease development due to its climate and its economy - with a great number of workers exposed to sunlight - this research aims to retrospectively study the pathological types of $\mathrm{CM}$ in a period of 11 years, to identify potential risk factors, describe anatomic location and assess Clark levels and Breslow thickness.

\section{MATERIALS AND METHODS}

Retrospective, descriptive and quantitative research of histopathological types of CM in Palmas, in the period from 2001 to 2011, from the record of Serviços de Anatomia Patológica de Palmas (SAPP) and Registro de Câncer de Base Populacional de Palmas (RCBPP).

\section{Inclusion criteria}

Patients with histopathologic diagnoses of CM in the period from 2001 to 2011, from the records of Serviços de Anatomia Patológica de Palmas (SAPP) and Registro de Câncer de Base Populacional de Palmas (RCBPP).

The study included patients living in Palmas, all ages, male and female, white and non-white, with any professions and sites of lesions.

\section{METHODS}

Searches were performed along with anatomic pathology laboratories located in Palmas accredited by the Conselho Regional de Medicina do Estado do Tocantins: Centro Diagnóstico em Anatomia Patológica (CDA); Mário Neto Medicina Laboratorial (MNML); Laboratório de Anatomia Patológica e Citologia (LAPAC); Laboratório Médico Laborato Ltda. (LABNORT); Laboratório Imuno Ltda. (MEDLABOR); and Centro Oncológico do Brasil (COBRA), which is responsible for the biopsies from public hospitals in Palmas. Searches were also conducted along with the Registro de Câncer de Base Populacional de Palmas (RCBPP), which is linked to the Secretaria Estadual de Saúde de Tocantins (SESAU-TO) and has been active since 2000 .

The identified variables were age, gender, race, profession, location of the lesion, histopathological type, Clark level and Breslow thickness. Available data did not permit to infer the time of residence in Palmas.

Data were plotted, analyzed and interpreted with the systems Epilnfo 2000 and Microsoft Office Excel using descriptive statistics.

The Informed Consent (IC) was applied to the pathologists who participated in the histopathological diagnosis. dential.

All data of the registered patients were confi-

The study was approved by Comitê de Ética em Experimentos em Seres Humanos of the Universidade Federal do Tocantins, according to protocol 075/2011 of March 23, 2012.

\section{Histopathologic types:}

According to its pathological types, CM is traditionally classified into:

1- Superficial spreading melanoma (SSM): characterized by a radial growth phase consisting of large anaplastic melanocytes, which creep between keratinocytes of the epidermis, following a pagetoid pattern. The follicular epithelium and the eccrine duct may also be involved in a similar way. ${ }^{18,9,10,11}$

2- Nodular melanoma (NM): a melanoma subtype that has exclusively a vertical growth phase. Microscopic small increase allows observing an elevated tumor, dome-shaped or polypoid. The overlying epidermis is thin and can be eroded or ulcerated. Melanoma cells may be present in the overlying epidermis, but not along the dermal component margins of the edge of the lesion. The dermal component is represented by a cohesive nodule or small nests of tumor cells with expansive growth pattern. Cells are often epithelioid, but other cell types, including spindle cells, small epithelioid cells similar to nevus cells, and mononuclear or multinucleated giant cells, may dominate or be mixed with other cell types. ${ }^{1,12,13}$

3- Lentigo maligna melanoma (LMM): characterized by atypical junctional proliferation of melanocytes arranged side by side along the basal layer, which may also be present in the basal layer of hair follicles and eccrine duct. The skin is atrophic and, in the dermis, there is a marked degree of solar elastosis. Although the junctional proliferation can form a confluent linear pattern in some areas, other regions may present atypical melanocytes interspersed among basal keratinocytes. Irregular junctional nests of atypical melanocytes may be present, as well as multinucleated giant cells. Marked pleomorphism is characteristic of atypical melanocytes presenting cytoplasmic retraction artifact and star-shaped, ovoid or crescent nuclei - some pressed against the cell wall. Lymphocytic infiltrate and focal fibroplasia along with intense solar elastosis and telangiectasia are observed in the papillary dermis. ${ }^{1,14}$

4- Acral lentiginous melanoma (ALM): in the radial growth phase, there is marked acanthosis and 
hyperkeratosis, elongation of the interpapillary crests and proliferation of atypical melanocytes along the basal layer of the epidermis at the periphery of the tumor. The intradermal component is represented by large atypical melanocytes with large nuclei and nucleoli, often bizarre, and cytoplasm containing large amount of melanin pigment. Melanocytes often have long dendrites surrounding keratinocytes. Atypical melanocytes can also be observed over the sweat ducts and even in the reticular dermis. In ALM vertical growth phase, tumor nodules contain predominantly spindle cells and are associated with desmoplastic reaction. The junctional component of thicker tumors shows formation of nests and migration of anaplastic melanocytes toward the stratum corneum. ${ }^{1,11,15}$

In this study, in addition to the 4 classic melanoma types, we also considered: CM in situ, metastatic $\mathrm{CM}$ (MCM) with no identification of the primary lesion, other less common types of $\mathrm{CM}$ and undefined $\mathrm{CM}$ (no histopathological classification).

CLARK LEVELS: LEVEL I: melanoma cells are present only in the epidermis and adnexal epithelium featuring a melanoma in situ; LEVEL II: melanoma cells occupy the papillary dermis with only a few cells present in the interface between the papillary and reticular dermis. This is a microinvasive melanoma; LEVEL III: melanoma occupies the entire papillary dermis to the superficial vascular plexus but without invading the reticular dermis; LEVEL IV: the cancer is invasive and tumorigenic, penetrating the reticular dermis; LEVEL $\mathrm{V}$ : the cancer invades the hypodermis. ${ }^{12,16,17,18,19,20}$

BRESLOW THICKNESS: $\leq 1 \mathrm{~mm}$ : tumor thickness $\leq 1 \mathrm{~mm}$; $1.01 \mathrm{~mm}$ to $2 \mathrm{~mm}$ : tumor thickness from $1.01 \mathrm{~mm}$ to $2 \mathrm{~mm} ; 2.01 \mathrm{~mm}$ to $4 \mathrm{~mm}$ : tumor thickness from $2.01 \mathrm{~mm}$ to $4 \mathrm{~mm}$; $>4 \mathrm{~mm}$ : tumor thickness greater than $4 \mathrm{~mm} \cdot{ }^{9,18,21,22,23,24}$

\section{RESULTS}

Ninety-five patients with diagnosis of $\mathrm{CM}$ were found, and 50 of them were excluded: 23 because they live in other cities of Tocantins; 20 for not having identified the city of residence; 6 because they live in cities in other states; and 1 because he was diagnosed outside the research period. Therefore, 45 patients were analyzed.

The year 2004 had the highest frequency of CM in Palmas (8 cases/ 17.8\%), followed by 2008 and 2011 (7 cases each/ 15.6\%) and 2010 (6 cases/ 13.3\%). In 2001 and 2009 , there were 4 cases $(8.9 \%)$ of CM in each period. In 2007, 3 cases were reported (6.7\%). 2003 and 2005 had 2 cases each (4.4\%), and 2002 and 2006 had 1 case each (2.2\%) (Graph 1).

The highest frequency occurred in patients be- tween 41 and 60 years old (19 cases/ 42.2\%), followed by those from 61 to 80 years old (14 cases/ 31.1\%). In the age group of $21-40$ years, 8 cases $(17.8 \%)$ were reported and in the group of $81-100$ years, 4 cases $(8.9 \%)$ were registered. The study did not detected patients aged 0-20 years. In the age group of 41-60 years, 2 distinct primary $\mathrm{CM}$ were recorded in 2 patients: a 43-year-old female and a 56-year-old male (Table 1). Mean age of patients was $54.9 \pm 16.1$ years, with a median of 52 years - the minimum age was 23 years and maximum was 89 years. The incidence peak occurred between the 4 th and the 6 th decade.

Comparing age and profession, there was a higher frequency among those in working age. Among the farmers, there were 10 men and 1 woman (Table 2).

Of the 45 patients, $25(55.6 \%)$ were female and $20(44.4 \%)$ were male (Graph 2). Furthermore, 23 $(51.2 \%)$ patients were white, $20(44.4 \%)$ were brown and $2(4.4 \%)$ were black (Graph 3$)$.

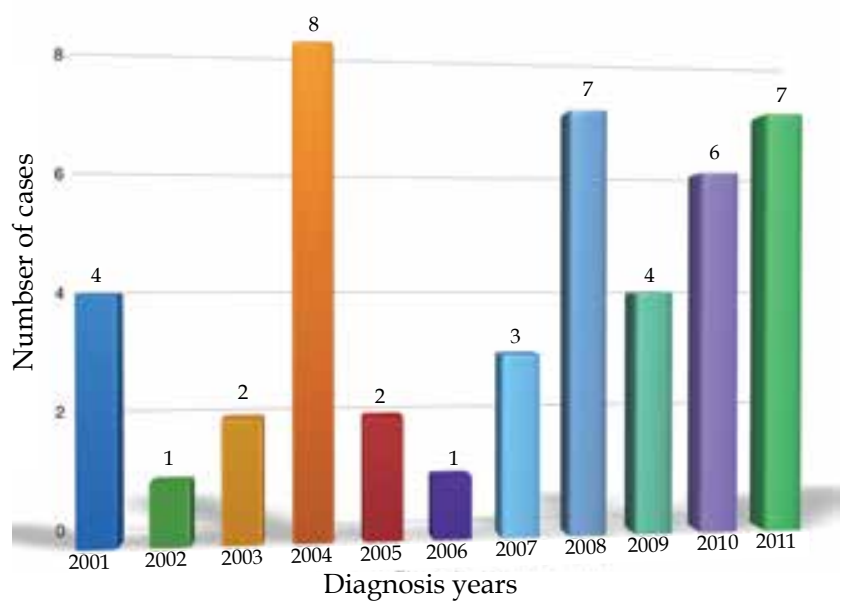

GRAPH 1: Distribution of cutaneous melanoma in Palmas-TO, from 2001 to 2011, according to year of diagnosis

TABLE 1: Distribution of cutaneous melanoma in Palmas-TO, 2001-2011, by age group

\begin{tabular}{lcl}
\hline Age (years) & Patients (n) & \% \\
\hline 0 to 20 & 0 & 0.0 \\
21 to 40 & 8 & 17.8 \\
41 to 60 & 19 & 42.2 \\
61 to 80 & 14 & 31.1 \\
81 to 100 & 4 & 8.9 \\
Total & $\mathbf{4 5}$ & $\mathbf{1 0}$ \\
\hline
\end{tabular}


TABLE 2: Distribution of cutaneous melanoma in Palmas-TO, from 2001 to 2011, according to age and profession

\begin{tabular}{|c|c|c|c|c|c|c|c|}
\hline \multirow[t]{2}{*}{ Age } & \multicolumn{7}{|c|}{ Profession } \\
\hline & Farmer & Housewife & Teacher & Businesswoman & $\begin{array}{l}\text { Government } \\
\text { employee }\end{array}$ & Other & NI \\
\hline 0 to 20 & 0 & 0 & 0 & 0 & 0 & 0 & 0 \\
\hline 21 to 40 & 0 & 0 & 1 & 1 & 0 & 6 & 0 \\
\hline 41 to 60 & 5 & 2 & 2 & 1 & 2 & 7 & 1 \\
\hline 61 to 80 & 4 & 6 & 0 & 0 & 0 & 1 & 3 \\
\hline 81 to 100 & 2 & 0 & 0 & 0 & 0 & 0 & 1 \\
\hline Total & 11 & 8 & 3 & 2 & 2 & 14 & 5 \\
\hline
\end{tabular}

N.I. = not identified

Profession vs. Age group

There was a higher occurrence in farmers (11 cases/ $24.4 \%$ ), followed by housewives ( 8 cases/ $17.8 \%$ ), teachers (3 cases/ 6.7\%) and businesswoman (2 cases/ $4.4 \%$ ). Two patients were registered only as public servants and other professionals presented only 1 case each $(2.2 \%)$ : veterinarian, cook, health agent, bank tell-

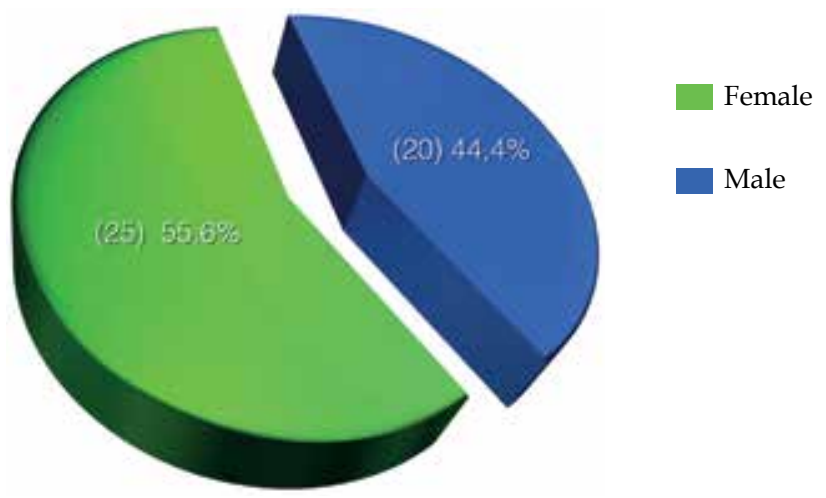

Graph 2: Distribution of cutaneous melanoma in Palmas-TO, from 2001 to 2011 according to sex

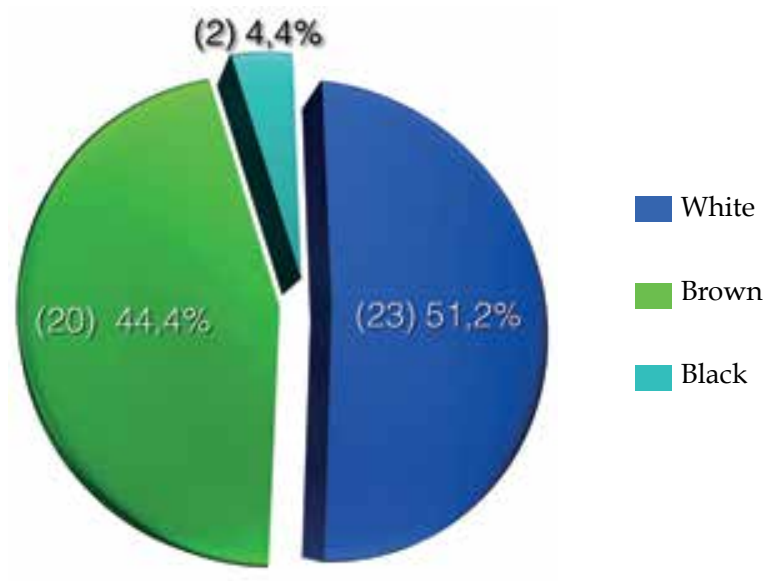

Graph 3: Distribution of cutaneous melanoma in Palmas-TO, from 2001 to 2011, according to skin color er, mototaxi driver, driver, security guard, manicure, human resources analyst, electrical engineer, manager, packer, administrative assistant and psychologist. In 5 cases $(11.1 \%)$ the profession has not been identified (Table 3).

Trunk was the site with a higher frequency of lesions with 16 cases (35.6\%), followed by lower limbs, with 10 cases $(22.2 \%)$. In the upper limbs and on the face 7 cases $(15.6 \%)$ were recorded. There were 2 cases $(4.4 \%)$ in the head, and 1 case $(2.2 \%)$ in the buttock. In only 2 cases $(4.4 \%)$, the location was not identified (Table 4).

TABLE 3: Distribution of cutaneous melanoma in Palmas-TO, from 2001 to 2011, by profession

\begin{tabular}{lll}
\hline Profession & N. of patients & \% \\
\hline Farmer & 11 & 24.4 \\
Housewife & 8 & 17.8 \\
Not identified & 5 & 11.1 \\
Teacher & 3 & 6.7 \\
Businesswoman & 2 & 4.4 \\
Government employee & 2 & 4.4 \\
Veterinarian & 1 & 2.2 \\
Cook & 1 & 2.2 \\
Healthcare provider & 1 & 2.2 \\
Bank teller & 1 & 2.2 \\
Mototaxi driver & 1 & 2.2 \\
Security guard & 1 & 2.2 \\
Manicure & 1 & 2.2 \\
Human Resources analyst & 1 & 2.2 \\
Electric engineer & 1 & 2.2 \\
Manager & 1 & 2.2 \\
Packer & 1 & 2.2 \\
Administrative assistant & 1 & 2.2 \\
Psychologist & 1 & 2.2 \\
Total & 45 & $\mathbf{1 0 0}$ \\
\hline
\end{tabular}


TABLE 4: Distribution of cutaneous melanoma in Palmas-TO, from 2001 to 2011, by location of the lesion

\begin{tabular}{lcl}
\hline Location & N. of patients & $\mathbf{\%}$ \\
\hline Trunk & 16 & 35.6 \\
Lower limbs & 10 & 22.2 \\
Superior limbs & 7 & 15.6 \\
Face & 7 & 15.6 \\
Head & 2 & 4.4 \\
Not identified & 2 & 4.4 \\
Buttock & 1 & 2.2 \\
Total & $\mathbf{4 5}$ & $\mathbf{1 0 0}$ \\
\hline
\end{tabular}

Considering gender separately, there were 7 cases $(15.6 \%)$ of lesions in the trunk in men and 9 cases $(20 \%)$ in women. Also, there were 4 cases $(8.9 \%)$ in the lower limbs in men and $6(13.3 \%)$ in women. Comparing the occurrence of lesions in the trunk between men and women, we observed a higher frequency in women.

The most common histological types were $\mathrm{CM}$ in situ, SSM and MCM, with 9 cases each (20.0\%). NM occurred in 8 cases $(17.7 \%)$, ALM in $3(6.7 \%)$ and LMM in $1(2.2 \%)$. In the case of MCM, the primary lesion was not identified. Of the 45 cases, $3(6.7 \%)$ were designated as "others", and $3(6.7 \%)$ were classified as "pathological type not defined" (no histopathological classification). A 36-year-old patient presented NM secondary to giant nevus followed by axillary metastasis; a 49-yearold patient presented melanoma secondary to melanocytic nevus; and a 73-year-old patient had desmoplastic melanoma. The 3 cases of ALM were detected in a 64-year-old woman, black, housewife, in the left plantar region; in a 75-year-old woman, black, unidentified profession, in the right plantar region; and in 86-yearold man, brown, farmer, in the right calcaneal region. The 3 undefined cases occurred in 3 female patients in the years 2003, 2004 and 2008 (Graph 4).

Regarding Clark level, 9 patients (20\%) presented level I; 7 (15.6\%) level II; 6 (13.3\%) level III; 8 (17.7\%) level IV; and $3(6.7 \%)$ level V. In 9 patients $(20.0 \%)$ Clark level was not applied because it was MCM with unknown primary origin. In 3 patients $(6.7 \%)$, Clark level was not defined (Table 5).

According to the American Joint Committee on Cancer (AJCC - 2002-2009), the study found 16 patients (35.5\%) with Breslow thickness $\leq 1 \mathrm{~mm} ; 4$ patients $(8.9 \%)$ with thickness between $1.01 \mathrm{~mm}$ and $2 \mathrm{~mm}$; 11 patients $(24.4 \%)$ with thickness from $2.01 \mathrm{~mm}$ to 4 $\mathrm{mm}$; and 2 patients $(4.4 \%)$ with thickness $>4 \mathrm{~mm}$. In 9 patients $(20.0 \%)$, Breslow thickness was not applied (MCM without detection of the primary lesion) and in 3 cases $(6.7 \%)$, this criterion was not defined (Table 6).

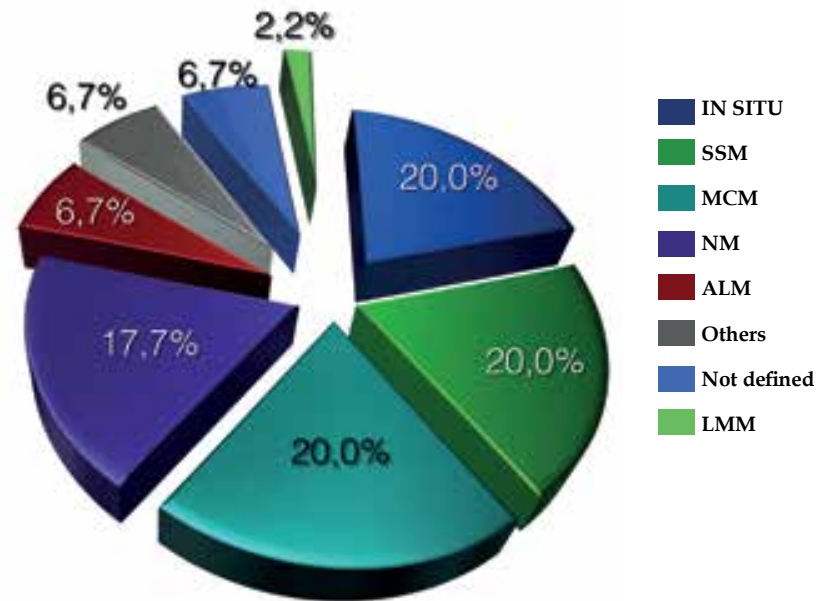

IN SITU: melanoma in situ; SSM: superficial spreading melanoma; MCM: metastatic cutaneous melanoma; NM: nodular melanoma; ALM: acral lentiginous melanoma; LMM: lentigo maligna melanoma

GraPH 4: Distribution of cutaneous melanoma in Palmas-TO, from 2001 to 2011, according to the histopathologic type

TABLE 5: Distribution of cutaneous melanoma in Palmas-TO, from 2001 to 2011, by Clark level

\begin{tabular}{lcl}
\hline Clark Level & N. of patients & \% \\
\hline I & 9 & 20.0 \\
II & 7 & 15.6 \\
III & 6 & 13.3 \\
IV & 8 & 17.7 \\
V & 3 & 6.7 \\
Not applicable & 9 & 20.0 \\
Not defined & 3 & 6.7 \\
Total & $\mathbf{4 5}$ & $\mathbf{1 0 0}$ \\
\hline
\end{tabular}

TABLE 6: Distribution of cutaneous melanoma in Palmas-TO, from 2001 to 2011, according to Breslow thickness

\begin{tabular}{lcl}
\hline Breslow thickness & N. of patients & \% \\
\hline$\leq 1 \mathrm{~mm}$ & 16 & 35.6 \\
$1.01 \mathrm{~mm}$ to $2 \mathrm{~mm}$ & 4 & 8.9 \\
$2.01 \mathrm{~mm}$ to $4 \mathrm{~mm}$ & 11 & 24.4 \\
$>4 \mathrm{~mm}$ & 2 & 4.4 \\
Not applicable & 9 & 20.0 \\
Not defined & 3 & 6.7 \\
Total & $\mathbf{4 5}$ & $\mathbf{1 0 0}$ \\
& & \\
\hline
\end{tabular}




\section{DISCUSSION}

This study aimed to survey CM scenario in the city of Palmas, in order to identify possible predictors or facilitating aspects present in workers, which may be addressed in preventive health activities in public or private healthcare systems.

In the data analysis of skin cancer prevention campaigns promoted by Sociedade Brasileira de Dermatologia (SBD) from 1999 to 2005, 205,869 subjects were examined and 1,057 cases of melanoma were diagnosed, corresponding to $8.7 \%$ of cancer cases in the examined subjects. The prevalence ratio between men and women was 1.7, and the proportion of cancer according to the race was: $1.6 \%$ in blacks; $3.2 \%$ in yellows; $3.4 \%$ in browns; and $12.7 \%$ in whites. The states with the highest prevalence were Santa Catarina and Rio Grande do Norte. More than $50 \%$ of the examined subjects were exposed to the sun without protection, which reinforces the importance of educational prevention activities. ${ }^{25,26}$

Sortino-Rachou et al (2006), analyzing the incidence, mortality and trends of MC in Goiânia-GOBrazil, found 290 new cases of CM in residents in the city of Goiania, with similar frequency between men and women. The age at diagnosis ranged from 5 to 98 years, with a median age of 54 years. In the current study, age ranged from 23 to 89 years with a median age of 54.9 years. ${ }^{27}$

The present study showed predominance of the disease among women and whites. However, the number of browns was significant. This is probably due to the large number of brown people in Palmas by regional and national racial mixture.

In the analysis of Sortino-Rachou et al (2006), 241 cases $(83.1 \%)$ had no morphological classification and more than half were invasive CM $(56.9 \%)$ according to Breslow thickness. Hips and legs and also head and neck were the predominant sites, with 75 cases $(25.9 \%)$ each. In our study, the primary lesion was located in the trunk, due to probable intermittent sun exposure. ${ }^{27}$

Maldonado et al divided the melanomas into two groups: those that occurred in skin with intermittent or rare sun exposure, which included trunk, upper and lower limbs and acral members; and those occurring in skin chronically exposed to sun, such as head and neck. Some authors argue that the areas of intermittent sun exposure and with severe sunburns are more likely to develop $\mathrm{CM} .{ }^{28}$

Lang et al (2005) also accessed the sun damage according to the place of origin of the lesion, but head, neck and hands in both sexes and legs among women were considered as constantly exposed areas. Trunk and arms in both sexes and legs among men were defined as areas subject to intermittent sun exposure. ${ }^{29}$
Deichmann et al (2006) considered the lesions located in head, face or dorsal region of hands as chronically exposed to UV radiation. In our study, the presence of the disease was higher in trunk and lower limbs, and female was the predominant sex in both locations. ${ }^{30}$

In the assessment of pathological reports (496) of $\mathrm{CM}$ diagnosed in Florianópolis-SC, Weber et al (2007) observed that most were invasive (210) or metastatic melanomas (100). The most common histological type was SSM, with 117 cases (60\%); followed by NM, with 59 cases (30\%); ALM, with 12 cases $(6 \%)$; and LMM, with 4 cases $(2 \%) .{ }^{31}$ In this research, we identified 9 melanomas in situ, 24 invasive melanomas and 9 metastatic melanomas. The most common histological type in the traditional classification was SSM, with 9 cases; followed by NM, with 8 cases; ALM, with 3 cases; and LMM, with only 1 case. The tumor classification, as well as the determination of Clark levels and Breslow thickness in 33 patients $(74 \%)$, reflects the good quality in the diagnosis executed by the Pathological Anatomy Services involved in this research.

Battisti et al (2009) assessed the epidemiological profile and the mortality of patients with primary $\mathrm{CM}$ in Florianópolis-SC, using similar methodology (pathological reports) between 2002 and 2003. The study observed 75 patients, $42(56 \%)$ women and $33(44 \%)$ men. ${ }^{23}$ In an epidemiological study of $\mathrm{CM}$ in 30 years, from 1980 to 2009, in the city of Blumenau-SC, Nasser considered only histopathological examinations with definitive diagnoses of CM (1,002 cases). The study population was composed of $94.5 \%$ Caucasians, mostly descendants of German and Italian immigrants, with skin types I and II. The study found $56 \%$ of melanomas in women. The disease occurred more frequently in the chest (47\%), $64.5 \%$ in men and $35.5 \%$ in women, followed by the lower limbs, $56.3 \%$ in women and $44,7 \%$ in men. There was a predominance of SSM (315 cases/ 51.6\%), and NM (233 cases/ 37\%) pathological types. Regarding Clark levels, levels II (234 cases) and IV (199 cases) predominated. And concerning Breslow thickness, a thickness of $\leq 1 \mathrm{~mm}$ (262 cases) predominated, followed by a thickness of $>2 \mathrm{~mm}$ (117 case). ${ }^{32,33}$

Konrad et al (2011), in Criciuma-SC, also studied CM by pathological reports. Most reports assessed revealed melanoma in situ (29.6\%), followed by tumor thickness $\leq 0.75 \mathrm{~mm}(25 \%)$ and from 0.76 to $1.5 \mathrm{~mm}$ $(23.4 \%)$. There was a prevalence of thickness $\leq 0.76 \mathrm{~mm}$ in women, with 11 cases $(28.9 \%)$, which may represent a greater health care. ${ }^{34}$

These authors studied 72 patients, and 65 of them had Clark level determined: level III was the most common among women (38.4\%) and level I among men (34.6\%). ${ }^{34}$ 
Among the 45 patients in our study, 33 had Clark level determined, and most of them was classified in levels I and IV, corresponding respectively to $20 \%$ and $17.7 \%$. Clark level is of secondary importance in CM staging, except for cases of thin melanomas. Clark level is an independent predictor of thin melanoma, but not for thicker lesions. Thus, the level of invasion is only incorporated in the definitions of melanomas $\leq 1 \mathrm{~mm} .^{24}$

Comparing the findings of Konrad et al (2011) with our study in Palmas, we can observe a correlation as to age $>50$ years, female gender, white, location of lesions in the trunk and lower limbs, women being the most affected in both locations, pathological type SSM followed by NM. It is noteworthy that in our research we considered primary and metastatic skin lesions and we use "trunk" nomenclature and not "chest". Regarding Clark level, there was agreement on level I and disagreement on level III. Finally, Breslow thickness also showed similar results, with the highest frequency of thickness $\leq 1 \mathrm{~mm}$, followed by thickness from $2.01 \mathrm{~mm}$ to $4 \mathrm{~mm}$. However, the study in Palmas-TO showed equality in smaller thicknesses for both sexes: $50 \%$ each.

Creating a database with as much relevant information in reference services for CM care is an important factor. Thus, the proper completion of medical records and histopathological reports with the appropriate morphological classification would facilitate the guidance to the monitoring of patients and would be a safe source for further research on the disease. Additionally, the address and the residence time in Palmas are important information for evaluating time of sun exposure and development of the CM in these patients.

Prevalence and risk of $\mathrm{CM}$ are still high in man, because they have less skin care, minor aesthetic concern (considered a female concern), lower attendance at prevention campaigns against skin cancer and less adherence to sun protection. In the present study, the inclusion of the profession of patients allowed us to conclude that the high frequency among farmers is related to the intense sun exposure without sunscreen and appropriate clothing for the performance of these activities. The finding of a significant number of housewives patients can be justified by the performance, without adequate protection, of various outdoors domestic activities, typical of the region, such as: washing clothes in rivers, lakes and other bodies of water; planting gardens; tidying up around the house; collecting materials for handicraft production (e.g., golden grass, babassu coconut and others). Another justification for this number would be the forms of leisure in the city: physical activities in general, fisheries and recreation under the sun with inadequate or even no protection.
People with chronic prolonged sun exposure sailors and farmers - are the highest risk group and, in this case, the possibility of developing skin cancer increases markedly with aging. Other groups of people working outdoors in the sun should also constitute a risk group for development of these neoplasms, such as construction workers and postmen, etc. ${ }^{35}$

The analysis of the studies in Tocantins (Palmas), Goiás (Goiânia) and Santa Catarina (Florianópolis, Blumenau and Criciuma) using the database methodology (anatomopathological examination) found that CM occurs more often in women; white; with a mean age of 50 years; and that the most frequent type was SSM, with Clark levels III and IV. In our study the predominant Clark level was I and IV, therefore being partially discordant with the other mentioned cities. ${ }^{36}$ The most common Breslow thickness was $\leq 1$ $\mathrm{mm}$. In the city of Florianópolis, Clark level was not determined and in none of these studies the profession of patients was addressed. Currently, few studies in the Brazilian literature mention the profession. Determination of the profession of patients is relevant in this study because it is a factor closely related to the disease development, especially when there is sun exposure.

To advance the education of the population is necessary to promote a change in lifestyle and habits in general, such as: modification in the workschedule of workers exposed to sun in Palmas, with protection from $9 \mathrm{am}$ to $5 \mathrm{pm}$; correct use of personal protective equipment (PPE); proper use of sunscreens; availability of these sunscreens in the public health system; appropriate clothing; use of hats and caps, umbrellas and parasols. Strategies for primary protection and early diagnosis of CM are fundamental. ${ }^{37}$

\section{CONCLUSIONS}

The most common histological types of $\mathrm{CM}$ found in Palmas, from 2001 to 2011, were: in situ, SSM and MCM, followed by NM and other forms.

The study on CM frequency in Palmas revealed that the number of affected patients in working age was $60 \%$, which indicates damage to employers and employees, more social security benefits and, thus, strong financial impact on the budget of public and private healthcare systems.

The greater importance of thin melanomas was revealed by Clark level and Breslow thickness.

The profile was similar to previous studies using the same methodology, and we highlight the inclusion of the profession of the patients. The predominance of farmers indicates sun exposure without adequate protection.

Thus, public education and use of appropriate clothing, caps, hats, umbrellas, parasols and sun- 
screens, as well as an adequacy of work schedule, avoiding sun exposure from $9 \mathrm{am}$ to $5 \mathrm{pm}$ are necessary.]

\section{ACKNOWLEDGMENT:}

To all who cooperated directly or indirectly with this research.

\section{REFERENCES}

1. Belfort F, Waisntein AJA. Melanoma, diagnóstico e tratamento. São Paulo: Lemar 2010.

2. Bakos L. Cutaneous melanoma: population-based studies in Brazil. An Bras Dermatol. 2006;81:402.

3. Ribeiro $A M Q$. Fatores prognósticos de melanoma cutâneo em um estudo de base populacional em Goiânia. [tese]. Brasília (DF): Universidade de Brasília; 2008.

4. Brasil. Ministério da Saúde. Instituto Nacional de Câncer José Alencar Gomes da Silva, Coordenação Geral de Ações Estratégicas, Coordenação de Prevenção e Vigilância. Estimativa da incidência de câncer no Brasil em 2012. Rio de Janeiro: INCA; 2011. 118p.

5. Brasil. Ministério da Saúde. Doenças relacionadas ao trabalho: manual de procedimentos para os serviços de saúde. Brasília (DF): 2001. 580p.

6. Schilling RSF. More effective prevention in occupational health practice. J Soc Occup Med. 1984;34:71-9.

7. Neves, RG, Lupi, 0, Talhari, S. Câncer da pele. Rio de Janeiro: Médisi; 2001.

8. Ackerman $\mathrm{AB}$. Malignant melanoma. A unifying concept. Am J Dermatopathol. 1980;2:309-13.

9. Balch CM, Sober AJ, Soong SJ, Thompson J, Atkins M, editors. Cutaneous melanoma. 5th ed. St. Luis Missouri: Quality Medical Publishing; 2009.

10. Sampaio SAP, Rivitti EA. Dermatologia. 3. ed. rev e ampl. São Paulo: Artes Médicas, 2007

11. Elder DE, Lever's histopathology of the skin. 10th ed. Philadelphia: Lippincott Williams \& Wilkins; 2009.

12. Fernandes NC, Calmon R, Maceira JP, Cuzzi T, Silva CSC. Cutaneous melanoma: prospective study of 65 cases. An Bras Dermatol. 2005;80:25-34.

13. LeBoit PE, Burg G, Weedon D, Sarasin A. Pathology and genetics of skin tumours World Health Organization classifications of tumours. IARC Press: Lyon; 2006. p.52-65.

14. Barnhill RL. Pathology of melanocytic nevi and malignant melanoma. 2th ed. New York: Springer; 2004.

15. Ferrari Jr NM. Estudo epidemiológico descritivo dos doentes de melanoma cutâneo acompanhados na Unidade de Melanoma da Santa Casa de São Paulo [dissertação]. São Paulo (SP): Universidade de São Paulo; 2006.

16. Clark WH Jr, Reimer RR, Greene M, Ainsworth AM, Mastrangelo MJ. Origin of familial malignant melanoma from heritable melanocytic lesions: "The B-K mole syndrome." Arch Dermatol. 1978;114:732-8.

17. Clark WH Jr, From L, Bernardino EA, Mihm MC. The histogenesis and biologic behavior of primary human malignant melanoma of the skin. Cancer Res. 1969;29:705-27.

18. Breslow A. Thickness, cross-sectional areas and depth of invasion in the prognosis of cutaneous melanoma. Ann Surg. 1970;172:902-8.

19. Mendonça GAS. Risco crescente de melanoma de pele no Brasil. Rev Saúde Públ. 1992; 26:290-4.

20. Balch CM, Murad TM, Soong SJ, Ingalls AL, Halpern NB, Maddox WA. A multifactorial analysis of melanoma: prognostic histopathological features comparing Clark's and Breslow's staging methods. Ann Surg. 1978;188:732-42.

21. Breslow A. Tumor thickness, level of invasion and node dissection in stage I cutaneous melanoma. Ann Surg. 1975;182:572-5.

22. Breslow A, Macht SD. Evaluation of prognosis is stage I cutaneous melanoma. Plast Reconstr Surg. 1978;61:342-6.

23. Battisti R, Nunes DH, Weber AL, Schweitzer LC, Sgrott I. Avaliação do perfil epidemiológico e da mortalidade dos pacientes com diagnóstico de melanoma cutâneo primário no município de Florianópolis - SC, Brasil. An Bras Dermatol. 2009;84:335-42.

24. Green FL, Page DL, Fleming ID, Fritz AG, Bach C, Haller DG, et al. AJCC Cancer Staging Manual. 6th ed. Chicago: Springer-Verlag; 2002.
25. Sociedade Brasileira de Dermatologia. Data analysis of the Brazilian Society of Dermatology skin câncer prevention campaign, 1999 to 2005. An Bras Dermatol. 2006; 81:533-9

26. Enokihara M. Situação epidemiológica do melanoma no Brasil. Boletim Informativo do GBM. 2010; 50:2.

27. Sortino-Rachou AM, Curado MP, Latorre MRDO. Cutaneous melanoma population-based study in Goiania, Brazil, from 1988 to 2000. An Bras Dermatol. 2006;81:449-55.

28. Maldonado JL, Fridlyand J, Patel H, Jain AN, Busam K, Kageshita T, et al Determinants of BRAF mutations in primary melanomas. J Natl Cancer Inst. 2003:95:1878-90.

29. Lang D, Lu MM, Huang L, Engleka KA, Zhang M, Chu EY, et al. Pax3 functions at a nodal point in melanocyte stem cell differentiation. Nature. 2005;433:884-7.

30. Deichmann M, Krahl D, Thome M, Wüst K, Hassanzadeh J, Helmke B. The oncogenic B-raf V599E mutation occurs more frequently in melanomas at sunprotected body sites. Int J Oncol. 2006;29:139-45.

31. Weber AL, Nunes DH, Souza Filho JJ, Pinto CJC. Assessment of 496 pathological reports of melanoma diagnosed in the city of Florianopolis, SC, Brazil. An Bras Dermatol. 2007; 82:227-32

32. Nasser N. Cutaneous melanoma: a 30-year-long epidemiological study conducted in a city in southern Brazil, from 1980-2009. An Bras Dermatol. 2011;86:932-41.

33. Freedberg IM, Eisen AZ, Wolff K, Austen KF, Goldsmith LA, Katz SI. Fitzpatrick's Dermatology in general medicine. 6th ed. New York: McGraw-Hill Companies; 2003.

34. Konrad P, Fabris MR, Melao S, Blanco LFO. Histopathological and epidemiological profile of cases of primary cutaneous melanoma diagnosed in Criciuma-SC between 2005 and 2007. An Bras Dermatol. 2011;86:457-61.

35. Popim RC, Corrente JE, Marino JAG, Souza CA. Câncer de pele: uso de medidas preventivas e perfil demográfico de um grupo de risco na cidade de Botucatu. Ciênc Saúde Coletiva. 2008:13:1331-6.

36. Bonfá R, Bonamigo RR, Bonfá R, Duro KM, Furian RD, Zelmanowicz Ade M. Early diagnosis of cutaneous melanoma: an observation in southern Brazil. An Bras Dermatol. 2011;86:215-21.

37. Eggermont AM, Spatz A, Robert C. Cutaneous melanoma. Lancet. 2014;383:81627.

MAILING ADDRESS:

Nilo Fernandes da Costa,

307 Sul, Rua 4, Lote 10, QI 24

Downtown

77.015-470 - Palmas TO

Brazil

E-mail:nfcdermatologista@hotmail.com

How to cite this article: Costa NF, Fernandes NC, Borges MRMM. Study of the histopathological types of cutaneous melanoma in Palmas-TO from 2001 to 2011. An Bras Dermatol. 2015;90(5):638-45. 